\title{
CUSTOMER PREFERENCE AND SATISFACTION LEVEL TOWARD ORGANIC VEGETABLE ATTRIBUTE (CASE STUDY ON TOP BUAH SEGAR CIBUBUR)
}

\author{
Evy Fausiah*1, Ma'mun Sarma*), and Mukhamad Najib*) \\ ${ }^{*}$ Department of Management, Faculty of Economics and Management, IPB University \\ Jl. Agatis, IPB Dramaga Campus Bogor 16680, Indonesia
}

\begin{abstract}
With the increasing public awareness of healthy lifestyles, the demand for organic agricultural products, especially vegetable products, currently continues to increase day by day. Therefore, it will require sufficient information and knowledge about the characteristics, preferences, and satisfaction of consumers with the attributes of organic vegetables to be used as a basis for understanding the needs for organic vegetable consumption. This study aimed to analyze consumer preference for organic vegetables and consumer satisfaction with organic vegetables' attributes. The data collection method used was the purposive sampling technique through distributing questionnaires to 140 respondents. Meanwhile, the data processing methods used in this study were conjoint analysis, IPA, and CSI. The result of the calculation of customer preference in this research showed that packaging was an indicator that had the highest level of importance at 28.99 percent. Hence, it needs innovation by describing the benefits and nutritional content of organic vegetables to increase consumer appeal. Based on IPA results, two attributes' performance had the highest priority to be improved by the company: affordable organic vegetable prices and organic vegetable discounts. Thus, the discounted prices are needed on specific days such as the Anniversary of the company and holidays. Furthermore, based on the CSI calculation results, the customers were considered satisfied with the performance of Top Buah Segar Cibubur.
\end{abstract}

Keywords: CSI, IPA, customer preference, customer satisfaction, organic vegetables

\begin{abstract}
Abstrak: Dengan semakin meningkatnya kesadaran masyarakat akan pola hidup sehat, saat ini permintaan produk pertanian organic khususnya pada produk sayuran semakin hari terus mengalami peningkatan. Sehingga, akan sangat dibutuhkan sebuah informasi dan pengetahuan yang cukup mengenai karakteristik, preferensi dan kepuasan konsumen terhadap atribut sayuran organic guna dijadikan dasar untuk mengetahui kebutuhan akan konsumsi sayuran organic. Penelitian ini bertujuan untuk menganalisis preferensi konsumen sayuran organik dan tingkat kepuasan konsumen terhadap atribut sayuran organik. Metode pengumpulan data yang digunakan berupa teknik purposive sampling melalui penyebaran kuesioner kepada 140 responden. Sedangkan, metode pengolahan data yang digunakan dalam penelitian ini yaitu analisis konjoin, IPA dan CSI. Hasil perhitungan dari preferensi konsumen dalam penelitian ini menunjukkan bahwa, kemasan merupakan indikator yang dianggap penting bagi konsumen dengan nilai sebesar 28.99 persen. Sehingga dibutuhkan suatu inovasi berupa deskripsi manfaat dan kandungan gizi sayuran organic guna meningkatkan daya tarik konsumen. Berdasarkan hasil IPA, terdapat dua atribut yang memiliki prioritas utama untuk diperbaiki kinerjanya oleh perusahaan yaitu harga sayuran organik terjangkau dan potongan harga sayuran organik. Oleh karena itu perlu adanya potongan harga di hari-hari tertentu seperti HUT perusahaan dan hari libur lainnya. Kemudian berdasarkan hasil perhitungan CSI didapatkan nilai sebesar 76.67 persen, dimana dari hasil perhitungan tersebut konsumen dinyatakan puas terhadap kinerja Top Buah Segar Cibubur.
\end{abstract}

Kata kunci: ipa, csi, preferensi konsumen, kepuasan konsumen, sayuran organik

\footnotetext{
${ }^{1}$ Corresponding author:

Email: evyfausiah@gmail.com
} 


\section{INTRODUCTION}

The food sector is highly needed in the community's life. Most of Indonesia's foods are produced from organic and inorganic agriculture managed by farmers or small-scale agriculture (Hubeis, Widyastuti, and Wijaya 2014). Nandan and Gami (2015) explained that organic agriculture is an agricultural production system that focuses on vegetables and fruits with a natural planting process without involving harmful chemical fertilizers and pesticides. Besides, Yadaf et al. (2013) explained that organic agriculture is a production system that avoids synthetic fertilizers, pesticides, and other chemical substances.

With the increasing awareness of healthy lifestyles, the current demand for organic agricultural products continues to increase. It is supported by the increasing area of organic agricultural land in Indonesia. According to Indonesian Organic Agriculture Statistics (2019), until 2018, Indonesia's total area of organic agricultural land reached 251,630.98 hectares. 122.01 hectares is land used for organic vegetables. Absolutely, with the increase in land area, there will be opportunities for businesses to market various types of organic vegetables. Thus, with these opportunities, sufficient information and knowledge about the characteristics, preferences, and consumer satisfaction with organic vegetables' attributes are required to be used as a basis for knowing the needs for organic vegetable consumption.

Organic vegetables are generated from natural farming processes that rely on natural elements so that the resulting products would not contain chemical elements. So far, organic vegetables are easier to find in big cities in Indonesia and generally marketed in specific modern markets or supermarkets. It is because consumers' price to obtain organic vegetables is relatively more expensive than inorganic vegetables. The wider community's tendency in selecting vegetables to be consumed generally prioritizes low prices rather than the quality of the vegetables themselves. Sari and Setiaboedhi (2017) explained that generally, organic products have a higher price than inorganic competitors due to higher raw material costs and more complicated processes. Chrysanthini et al. (2017) explained that the results of identifying organic vegetable consumer satisfaction showed that consumers generally preferred a fair price for organic vegetables. Thus, the interest in organic vegetables has not reached all groups of people who have below-average income.
Top Buah Segar Cibubur is a business engaged in organic and inorganic agricultural products. Every month, there are approximately 10,000 transactions at Top Buah Segar Cibubur. It is not certainly an insignificant value, considering that many businesses have sprung up and become competitors to Top Buah Segar Cibubur. Based on the owner's strong desire to serve vegetables and various home fruits, Top Buah Segar Cibubur always conducts evaluation to make all components in good condition. Thus, customers feel satisfied while shopping at Top Buah Segar Cibubur.

An evaluation conducted by Top Buah Segar Cibubur is by accepting suggestions and critics from customers such as checking fruit, vegetables, and various other products regularly so that the quality received by consumers is still in good condition and fresh. Since its establishment in 2008, Top Buah Segar Cibubur has always provided good-quality products to all customers to maintain its existence. However, it doesn't mean that what has been done from the beginning has no significant obstacles. The problems are always used as a lesson for Top Buah Segar Cibubur to improve the quality of products and services to consumers.

So far, the problem that often occurs in Top Buah Segar Cibubur is that there are complaints from consumers regarding the quality products of organic vegetables, such as rot on the inside of the vegetables. The sales of organic vegetables that tend to be stagnant are also a problem for Top Buah Segar Cibubur. Thus, based on this problem, the researcher conducted this research to analyze consumer preferences for organic vegetables and consumer satisfaction levels for organic vegetables' attributes. The research scope in respondent retrieval was consumers who had purchased organic vegetables once in the past month at Top Buah Segar Cibubur. It is intended that consumers can be more objective in evaluating indicators or attributes of organic vegetables.

The previous research only discussed consumer satisfaction using the Importance Performance Analysis (IPA) method and the Customer Satisfaction Index (CSI). Meanwhile, in this research, besides discussing the consumer satisfaction in purchasing organic vegetables, the researcher also discussed consumer preferences to find out what consumers consider while purchasing organic vegetables at Top Fresh Fruit Cibubur by looking at the indicators and levels that have been set in this research. 


\section{METHODS}

This research was conducted at Top Buah Segar Cibubur. The data collected in this research were primary data obtained directly through interviews with the person in charge of Top Buah Segar Cibubur and filling out questionnaires by respondents. The sampling technique used in this research was purposive sampling, which determined the sample with specific considerations (Sugiyono 2016). The respondents used in this research were consumers who have purchased organic vegetables once in the past month. The number of respondents was determined by multiplying the number of indicators with a range of 5 to 10 (Sugiyono 2016). This research used a maximum range of 10 , then multiplied by the number of indicators used in the research of 14 indicators. The number of respondents obtained was 140 respondents.

The data processing method used was conjoint analysis, IPA, and CSI. Conjoint analysis to measure consumer preferences for a product or service aims to obtain a utility score representing each attribute's interests. Thus, from this score, conclusions can be drawn about what indicators and levels consumers consider the most in choosing a product. Preference analysis in this research used four indicators that included types of vegetables, price, packaging, and labels. Meanwhile, the processing of conjoint analysis used XLStat and Microsoft Excel 2010 software. The formula of conjoint analysis is as follow:

$$
\mathrm{U}(\mathrm{X})=\sum_{j=1}^{k} \beta i j X i j
$$

Discription: U(X) (total utility); ßij (utility value of $\mathrm{i}$ attribute $\mathrm{j}$ level); $\mathrm{k}$ (level $\mathrm{j}$ of the $\mathrm{i}$ attribute); $\mathrm{m}$ (number of attributes); Xij (dummy variable for i attribute j).

The level of consumer satisfaction with organic vegetables' attributes was analyzed using the IPA and CSI analysis methods by determining four indicators, such as product, price, place, and promotion. There are 12 attributes of organic vegetables obtained based on literature studies. IPA is used to analyze the level of performance and importance to determine which attributes have low performance and should be improved. The formula of IPA, according to Supranto (2011), is as follows:

$$
\mathrm{Tki}=\mathrm{Xi} / \mathrm{Yi} \times \mathbf{1 0 0 \%}
$$

Discription: Tki (conformity level); Xi (performance appraisal score); Yi (importance rating score).

After getting the suitability level value, the next step is to find the average value for each attribute that consumers perceive. The formula used is as follows:

$$
\overline{\mathrm{Y}}=\sum \mathrm{Yi} / \mathrm{n} \quad \overline{\mathrm{X}}=\sum \mathrm{Xi} / \mathrm{n}
$$

Discription: $\overline{\mathrm{Y}}$ (average level of consumer interest); $\overline{\mathrm{X}}$ (average company performance level); Yi (total score of importance); Xi (total score of performance level); $\mathrm{n}$ (number of respondents).

Furthermore, the average of the attributes of the level of importance $(\mathrm{Y})$ and performance $(\mathrm{X})$, that were the Cartesian diagram's limits, was calculated. The formula is as follow :

$$
\overline{\overline{\mathrm{Y}}}=\frac{\sum_{i=1}^{n} Y i}{k} \quad \overline{\overline{\mathrm{X}}}=\frac{\sum_{i=1}^{n} X i}{k}
$$

Discription: $\overline{\mathrm{Y}}$ (Y-axis boundary (level of importance)); $\overline{\mathrm{X}}$ (X-axis limit (performance level)); $\mathrm{k}$ (number of attributes observed). The relation between the level of importance $(\mathrm{Y})$ and performance $(\mathrm{X})$ can be interpreted by the IPA diagram shown in Figure 1.Each quadrant in the figure shows a different state:

1.Quadrant I (Main Priority). This attribute is considered important, but the implementation of the attribute performance is still low. In this quadrant, the level of customer satisfaction is still low. Thus, the company needs to improve the performance of the attributes. The attributes in quadrant I have the highest priority to be improved, in terms of performance, by the company.

2.Quadrant II (Maintain The Achievement). The attributes are considered important, and the attribute performance is following what consumers feel. In this quadrant, customer satisfaction is considered relatively high. Thus, companies need to maintain the existing attributes in quadrant II.

3.Quadrant III (Low Priority). This attribute is considered less important by consumers with poor performance. The performance improvement of the attributes contained in this quadrant can be reconsidered because they have little effect on consumers.

4. Quadrant IV (exaggerated). Areas show satisfaction attributes with a low level of importance but have a high level of satisfaction. 
CSI is used to determine overall customer satisfaction by considering the measured attributes' importance and performance. IPA and CSI processing used SPSS version 22 and Microsoft Excel 2010 software. Based on Aritonang (2005), the CSI measurement method consists of the following steps:

1. Determining the Mean Expectation Score (MES) and Mean Performance Score (MPS). This value comes from the average level of importance and performance of each respondent.

$$
\mathrm{MES}=\frac{\sum_{i=1}^{n} Y i}{n} \quad \mathrm{MPS}=\frac{\sum_{i=1}^{n} X i}{n}
$$

Discription: $\mathrm{n}$ (number of respondents); Yi ( importance value of the $\mathrm{i}$ attribute); $\mathrm{Xi}$ (the performance value of the $i$ attribute)

2. Making a Weight Factor (WF). This weight is the percentage of the MES value per attribute to the total MES of all attributes.

$$
\mathrm{WF}=\frac{\mathrm{MES}}{\sum_{i=1}^{n} M E S i}
$$

3. Calculating the Weighting Score (WS), this weight is the multiplication of the Weighting Factor (WF) and the average level of satisfaction of the Mean Performance Score (MPS).

\section{Wsi $=$ Wfi $\times$ MPSi}

Discription: i (atribut)

4. Determining the value of the CSI

The CSI value is obtained using the following equation:

$$
\mathrm{CSI}=\frac{\sum_{i=1}^{n} W S i}{H S} \times 100 \%
$$

In which HS (High Scale) is the maximum scale used. The criteria for the level of customer satisfaction can be seen in Table 1.

The company's problems were usually complaints from consumers who thought the quality of the organic vegetables purchased was still not good. Besides, sales of organic vegetables that tend to stagnate were also a serious problem faced by Top Buah Segar Cibubur. The data analysis procedure used in this research included organic vegetable consumers' characteristics that were analyzed descriptively with several indicators, such as age, gender, education, occupation, marital status, and income (Sangadji and Sopiah, 2013). Furthermore, organic vegetable consumer preferences analyzed used conjoin analysis. Researchers analyzed several predetermined indicators, such as the types of vegetables that consumers often buy, the price of vegetables, and vegetable packaging. Then the researchers added the presence or absence of an organic label on the packaging. Furthermore, the level of consumer satisfaction with the attributes of organic vegetables was analyzed using the Importance Performance Analysis (IPA) and Customer Satisfaction Index (CSI) analysis methods by determining four indicators, namely product, price, place, and promotion (Kotler, 2011). It is expected that the results obtained will be able to add value to the company to provide satisfaction to consumers by providing quality products and fulfilling the needs of goods to consumers. The following is the framework for this research presented in Figure 2.

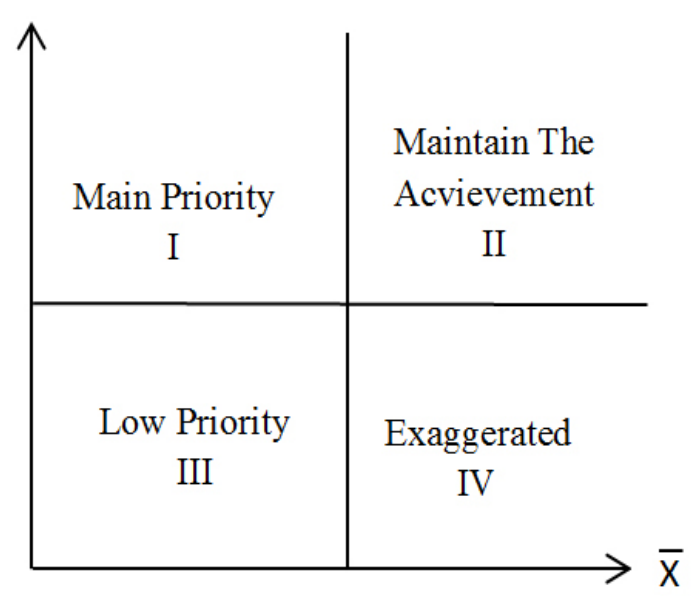

Figure 1. Diagram of Importance Performance Analysis (IPA) diagram

Table 1. The criteria for the consumer satisfaction index score

\begin{tabular}{ll}
\hline Index Value $(\%)$ & Information \\
\hline $0<\mathrm{CSI} \leq 20$ & Very unsatisfied \\
$21<\mathrm{CSI} \leq 40$ & Unsatisfied \\
$41<\mathrm{CSI} \leq 60$ & Satisfied enough \\
$61<\mathrm{CSI} \leq 80$ & Satisfied \\
$81<\mathrm{CSI} \leq 100$ & Very satisfied \\
\hline
\end{tabular}

Source: Aritonang (2005) 


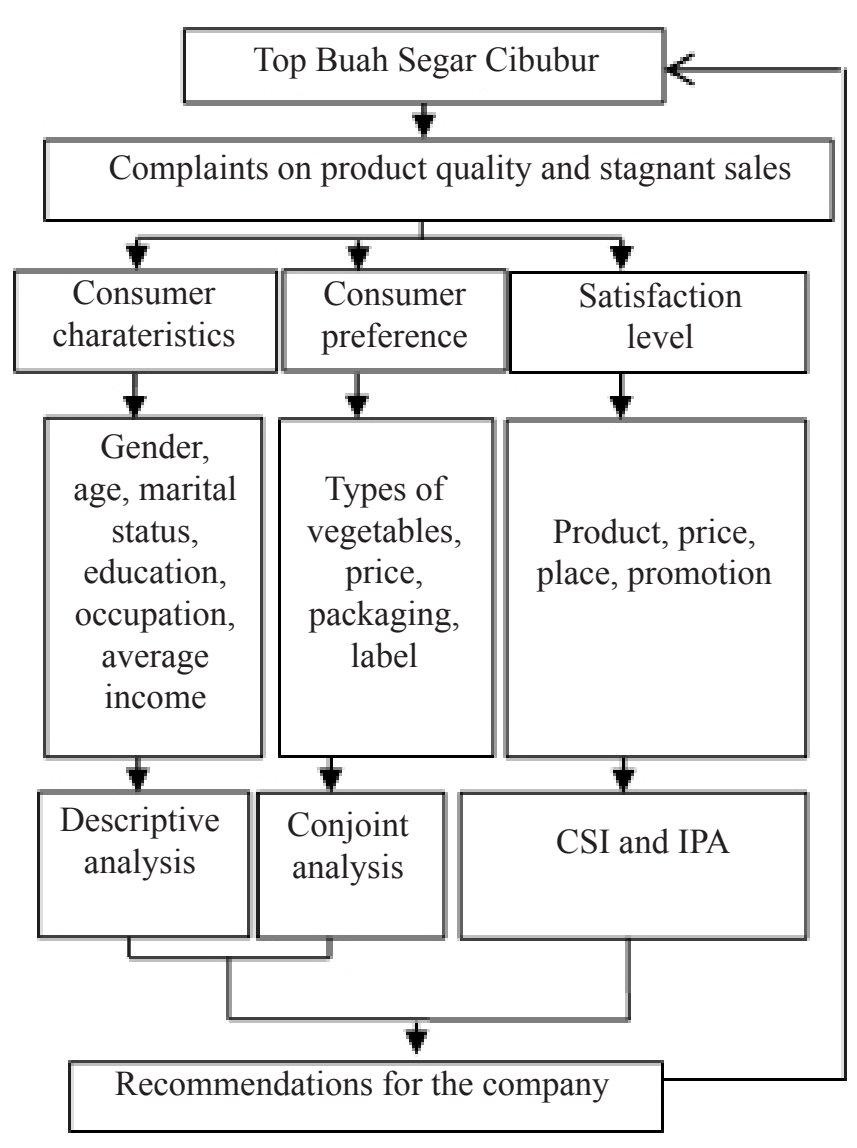

Figure 2. Research framework

\section{RESULTS}

\section{Respondent's Characteristic as Customer at Top Buah Segar Cibubur}

The research results showed that $70 \%$ of respondents involved in this research were women aged 17-27. This age range is the productive age. Thus, this age's composition and distribution can be a potential target market for developing organic vegetable marketing. As for the marital status, $58 \%$ of respondents in this research had not been married, and $42 \%$ were married. Meanwhile, concerning the occupation, respondents who worked as private employees were $50 \%$. In terms of the latest education, the ones who had undergraduate level were $55 \%$. The average monthly income of the respondents was Rp3,000,000-6,000,000 (44\%). Based on the respondent characteristics data, Top Buah Segar Cibubur needs to innovate to increase interest in shopping for organic vegetables through events such as bazaars, promotions through social media, or magazines that can attract market share outside of the current consumer image.

\section{Customer Preference toward Organic Vegetables}

Customer preference can be found out by measuring the value of the level of use and the relative importance of each attribute contained in a product (Herista, 2015). This research used a preference analysis with four indicators, including types of vegetables, price, packaging, and labels. Meanwhile, conjoint analysis processing used XLStat and Microsoft Excel 2010 software. The results of the consumer preference calculation for organic vegetables could be seen in Table 2 . The calculation results were packaging amounted to $28.99 \%$, labels $28.87 \%$, types of vegetables $27.53 \%$, and price $14.61 \%$. Besides, related to the calculation of the satisfaction level, in terms of types of vegetables, consumers tended to choose bok choy over other types of vegetables. Furthermore, for prices, consumers preferred prices that follow the conditions of organic vegetables. For packaging and labels, consumers chose to use plastic packaging and organic labeled.

Puspasari et al. (2017) explained that packaging is the most important indicator for consumers in making purchasing decisions. The more attractive the packaging used, the more the consumer interest in buying this product will increase. In addition to the organic label, according to Sutarni et al. (2017), the organic label is considered important for consumers in deciding to buy organic vegetables. It is because the organic label is a guarantee that shows that the vegetables purchased are products that are produced through stages that are free of chemicals. Dasipah et al. (2019) also explained that labeling is a guarantee for an organic product so that organic labeling should not be done carelessly but must meet specific requirements and must be done legally and specifically. Then related to the price, Yasmin et al. (2017) explained that price had the lowest assessment among all indicators. Consumers who buy vegetables have started to have a high awareness of healthy lifestyles, especially in consuming organic vegetables. Thus, the selling price of vegetables does not have a significant effect on consumer buying interest. Furthermore, the result of the research conducted by Sutarni et al. (2017) was that consumers considered that the critical factor in purchasing organic agricultural products was organic certificates on the product label. The second factor was the availability of organic products in supermarkets. The third factor was packaging on organic agricultural products, and the last factor was the price of the product. 
Table 2. Satisfaction level and relative importance

\begin{tabular}{|c|c|c|c|}
\hline \multirow{2}{*}{ Indicator } & \multicolumn{2}{|l|}{ Level } & \multirow{2}{*}{ Relative Importance Level (\%) } \\
\hline & Description & Utility Level & \\
\hline \multirow[t]{3}{*}{ Vegetable type } & Spinach & -0.034 & 27.53 \\
\hline & Kale & 0.008 & \\
\hline & Pokcoy & 0.026 & \\
\hline \multirow[t]{2}{*}{ Price } & In accordance with market price in general & -0.032 & 14.61 \\
\hline & In accordance with organic vegetable condition & 0.032 & \\
\hline \multirow[t]{2}{*}{ Packaging } & Using plastic for packaging & 0.150 & 28.99 \\
\hline & Not using plastic for packaging & -0.150 & \\
\hline \multirow[t]{2}{*}{ Label } & Labeled organic & 0.302 & 28.87 \\
\hline & Not labeled organic & -0.302 & \\
\hline
\end{tabular}

\section{Importance Performance Analysis (IPA)}

According to Suroto et al. (2018), Importance Performance Analysis (IPA) is an analysis tool used to analyze the level of importance and performance to determine which attributes have low performance and should be improved. In this research, customer satisfaction was assessed based on the respondent's assessment of the level of performance and importance level. Table 3 shows the assessment results conducted on 140 respondents.

Based on Rachmadita dan Arninputranto (2018), IPA aims to determine the position or comparison between perception and expectation attributes. The comparison is depicted in a diagram to determine consumers' priority through the four quadrants in the Cartesius diagram. Based on the data in Table 3, the analysis result showed that the average level of importance and the average performance level were obtained values of 4.19 and 3.83 , respectively. The two values will be the centerline on the IPA Cartesian diagram so that the Cartesian diagram will be divided into four quadrants. Each quadrant in the diagram describes a different situation. The $\mathrm{X}$-axis in the Cartesian diagram represents the attribute's performance, while the Y-axis represents its importance. IPA diagram showing the attributes of Top Buah Segar Cibubur is depicted in Figure 3.

\section{Quadrant I (The main priority)}

This quadrant shows attributes that are considered important, but the implementation of attribute performance is still low. In this quadrant, the level of customer satisfaction is still low. Thus, the company needs to improve the performance of the attributes in quadrant I. Attributes in quadrant-I have a top priority to improve their performance. Based on the results, the attributes contained in this quadrant were in the form of affordable organic vegetable prices and organic vegetable discounts.

\section{Quadrant II (The main priority)}

This quadrant shows attributes that are considered important by consumers. The level of customer satisfaction is considered relatively high. Thus, companies need to maintain attributes. The attributes in this quadrant were the freshness, durability, diversity, and price of organic vegetables according to the quality and availability of organic vegetables.

\section{Quadrant III (Low priority)}

This quadrant shows attributes that are considered to have an important effect on customers with a performance that is not very good. The improvement in the performance of the attributes contained in this quadrant can be reconsidered because they have little effect on consumers. The results of the attribute analysis contained in this quadrant were electronic media in marketing organic vegetables.

\section{Quadrant IV (exaggerated)}

This quadrant shows attributes with a low importance level but a high-performance level. The analysis results obtained were organic vegetable packaging, organic vegetable color, organic vegetable brand, and the ease of obtaining organic vegetables. 
Table 3. Calculation of the average of interest assessment and performance attributes of Top Buah Segar Cibubur

\begin{tabular}{llllc}
\hline Attribute & $\begin{array}{l}\text { Interest } \\
\text { assessment }\end{array}$ & $\begin{array}{l}\text { Performance } \\
\text { assessment }\end{array}$ & $\overline{\mathrm{Y}}$ & $\overline{\mathrm{X}}$ \\
\hline The packaging of organic vegetables & 561 & 559 & 4.00 & 3.99 \\
The freshness of organic vegetables & 664 & 576 & 4.74 & 4.11 \\
Color of organic vegetables & 578 & 549 & 4.12 & 3.92 \\
Brand of organic vegetables & 512 & 559 & 3.65 & 3.99 \\
The durability of organic vegetables & 633 & 551 & 4.52 & 3.93 \\
The kinds of organic vegetables & 590 & 540 & 4.21 & 3.85 \\
The price of organic vegetables is affordable & 603 & 516 & 4.30 & 3.68 \\
The price of organic vegetables is in accordance with the quality & 601 & 537 & 4.29 & 3.83 \\
The ease of obtaining organic vegetables & 576 & 539 & 4.11 & 3.85 \\
The availability of organic vegetables & 595 & 542 & 4.25 & 3.87 \\
Organic vegetable discounts & 587 & 490 & 4.19 & 3.50 \\
Electronic media in marketing organic vegetables & 551 & 477 & 3.93 & 3.40 \\
$\quad$ Total & & & 50.36 & 45.96 \\
& & & 4.19 & 3.83 \\
\hline
\end{tabular}

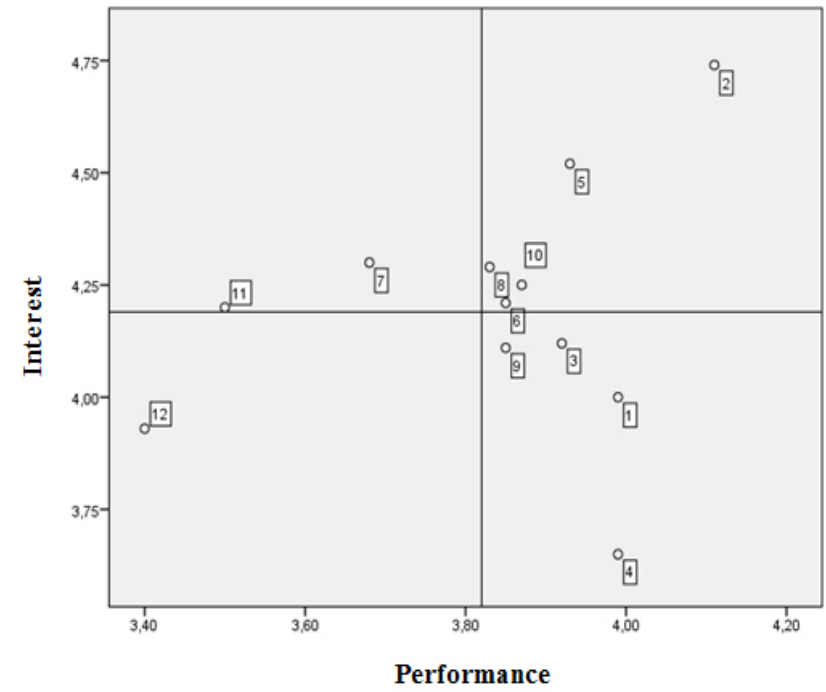

Figure 3. The results of the IPA diagram for the attributes of Top Buah Segar Cibubur

\section{Customer Satisfaction Index (CSI)}

CSI is used to determine customer satisfaction levels by considering the level of importance and performance level on the measured attributes. Lubis dan Andayani (2017) also added that customer satisfaction is a satisfaction viewed from the customer side regarding the service process provided compared with what they want. Besides, Alanazi and Bach (2016) defined consumer satisfaction as a commercial term or a measure of how a company's products and services can achieve or exceed customer expectations. CSI calculates the average value of the level of importance and the level of performance of these attributes to determine total customer satisfaction. The CSI analysis calculation begins by determining the weighted factor (wf) obtained from dividing the average value of each attribute's importance with the attributes' total level of importance. The wf value is used to calculate the value of the weighted score (ws) obtained from the multiplication of wf with the average value of each attribute's performance. The CSI value is obtained from the total value of ws divided by five (the number of scales used) and then multiplied by $100 \%$. CSI calculation can be seen in Table 4.

According to Table 3, the CSI value of $76.67 \%$ indicates that customers were satisfied with the performance of Top Buah Segar Cibubur. It also indicates that 23.33 percent of consumers are still not satisfied with the performance of Top Buah Segar Cibubur. Therefore, Top Buah Segar Cibubur needs to know which performance attributes have met and have not met consumer expectations. If the attribute performance was not according to consumer expectations, it is necessary to improve customer satisfaction attributes.

In the research conducted by Harimurti et al. (2016), the CSI value obtained was $69.64 \%$, ranging from 66 to 80 . It meant that consumers were satisfied with the performance of vegetables from Pasar Kecil Bandung. For the IPA results, several attributes' performance had the main priority to be improved, such as the variety of vegetables and packaging that could maintain the quality of vegetables. In Rusyadi (2014), the CSI value gained was $62.4 \%$, ranging from 60 to 80 . It meant that farmers were satisfied with the existing performance in the attributes. For IPA results, several attributes were 
felt by farmers to have low performance, such as the packaging quality, type of package, type of variety, expiration date, size of the seed, storage capacity, and easy access to seeds.

\section{Managerial Implication}

The company should consider adding a description of the benefits and nutritional content of each organic vegetable product. It is because the more attractive the packaging used, the more it is expected to be able to increase consumer buying interest in organic vegetable products. Consumers of organic vegetables at Top Buah Segar Cibubur put bok choy, prices according to organic vegetables, plastic packaging, and labeled organic as factors with the most preferred level of utility.

Based on the IPA result, some attributes' performance had the main priority to be improved. The first attribute was the affordable price of organic vegetables. In this attribute, the price of organic vegetables was considered unreachable by some circles. Among the 140 respondents who had shopped organic vegetables at Top Buah Segar Cibubur, 60 respondents stated such things. Therefore, an effort to improve Top Fresh Fruit Cibubur is evaluating the price of organic vegetable products. Ratnawati et al. (2017) stated that price is a factor that consumers consider in purchasing organic vegetables. It is because most consumers have allocated funds for other needs.

The next attribute is the organic vegetable discount. In terms of organic vegetable discount, among the 140 respondents, almost all expected a discount given by Top Buah Segar Cibubur to customers. Because if Top Buah Segar Cibubur implemented the discount system, it might increase the consumer interest in shopping for organic vegetables at Top Buah Segar Cibubur. Sarma et al. (2020) explained that generally, organic vegetables' selling price tends to be higher than inorganic vegetables. Thus, it needs Special discounts or prices offered on certain days such as Independence Day, Top Buah Segar Cibubur Anniversary, then Saturdays and Sundays to encourage consumer interest in buying organic vegetables regularly.

CSI calculation result indicated that $76.67 \%$ of consumers were satisfied with the performance of Top Fresh Fruit Cibubur. However, 23.33\% of consumers were still not satisfied with it. Therefore, Top Buah Segar Cibubur needs to know which performance attributes have met and have not met consumer expectations. Suppose the attribute performance is not following consumer expectations. In that case, it is necessary to improve attributes to increase consumer satisfaction, which will also increase organic vegetables' sales.

Tabel 4. The CSI calculation of Top Buah Segar Cibubur

\begin{tabular}{|c|c|c|c|c|}
\hline Attribute & $\begin{array}{c}\text { Importance } \\
\text { average }\end{array}$ & $\begin{array}{c}\text { Performance } \\
\text { average }\end{array}$ & WF & WS \\
\hline The packaging of organic vegetables & 4.00 & 3.99 & 0.08 & 0.31 \\
\hline The freshness of organic vegetables & 4.74 & 4.11 & 0.09 & 0.38 \\
\hline Color of of organic vegetables & 4.12 & 3.92 & 0.08 & 0.32 \\
\hline The brand of organic vegetables & 3.65 & 3.99 & 0.07 & 0.29 \\
\hline Durability of of organic vegetables & 4.52 & 3.93 & 0.09 & 0.35 \\
\hline Kinds of organic vegetables & 4.21 & 3.85 & 0.08 & 0.32 \\
\hline The price of organic vegetables is affordable & 4.30 & 3.68 & 0.08 & 0.31 \\
\hline The price of organic vegetables is in accordance with the quality & 4.29 & 3.83 & 0.08 & 0.32 \\
\hline The ease to obtain organic vegetables & 4.11 & 3.85 & 0.08 & 0.31 \\
\hline The availability of organic vegetables & 4.25 & 3.87 & 0.08 & 0.32 \\
\hline Discount of organic vegetables & 4.19 & 3.50 & 0.08 & 0.29 \\
\hline Electronic media in marketing organic vegetables & 3.93 & 3.40 & 0.07 & 0.26 \\
\hline Total & 50.36 & 45.96 & \multirow{2}{*}{\multicolumn{2}{|c|}{3.834}} \\
\hline \multirow[t]{2}{*}{ Average } & 4.19 & 3.83 & & \\
\hline & & CSI & \multicolumn{2}{|c|}{$76.67 \%$} \\
\hline
\end{tabular}




\section{CONCLUSIONS AND RECOMMENDATIONS}

\section{Conclusions}

In the analysis of consumer preferences, the results showed that packaging was an indicator that became a consideration for Top Buah Segar consumers in purchasing organic vegetables, followed by the label, type of vegetables, and price. Consumers of organic vegetables at Top Buah Segar Cibubur put bok choy, prices according to the condition of organic vegetables, plastic packaging, and labeled organic as factors that had the most preferred level of utility. Based on IPA results, two attributes' performance had the highest priority to be improved, namely affordable organic vegetable prices and organic vegetable discounts. Besides, based on the CSI calculation result, most consumers were satisfied with the performance of Top Fresh Fruit Cibubur.

\section{Recommendations}

The company needs to improve attributes that have the main priority for performance improvement: affordable organic vegetablepricesand organic vegetable discounts. According to consumer expectations, the company also needs to maintain the performance attributes, such as the freshness, durability, diversity, and price of organic vegetables according to the quality and availability of organic vegetables. The company should also provide discounts on organic vegetable products, especially on certain days such as weekends, Independence Day, and Top Buah Segar Cibubur Anniversary. Thus, consumers might be more loyal to shopping at Top Buah Segar. Besides, to increase consumer interest in consuming organic vegetables, the company needs to enhance its packaging. It could add the definition and benefits of organic vegetables so that consumers can find out information about organic vegetables sold at Top Buah Segar Cibubur. For further research, it is suggested to discuss consumer interest in shopping for organic vegetables at Top Buah Segar Cibubur and consumers' shopping restrictions during the pandemic. It is conducted to analyze the consumer interest in buying organic vegetables during the pandemic.

\section{REFERENCES}

Alanazi A, Bach C. 2016. Factors that affect and enhance customer satisfaction. Journal of Research in Business and Management 4(9): 80-88.

Aritonang Lerbin R. 2005. Kepuasan Pelanggan. Jakarta: PT Gramedia Pustaka Utama.

Chrysanthini B, Sumarwan U, Rifin A. 2017. Preferensi konsumen terhadap produk sayuran organik (studi kasus konsumen UD Fabela-Myfarm) di Bogor Jawa Barat. Journal of Development Management on Small Scale Industry 12(2):151160.

Dasipah E, Sukmawati D, Sofiatin R. 2019. Preferensi label dan persepsi kemudahan memperoleh produk terhadap keputusan pembelian sayuran organik. Jurnal Pemikiran Masyarakat Ilmiah Berwawasan Agribisnis 5(2):235-242.

Harimurti A C, Sadeli A H, Utami H N, Mukti G W. 2016. Strategi peningkatan kinerja atribut produk sayuran melalui pemasaran online dalam upaya meraih kepuasan konsumen (studi kasus di pasar kecil Bandung). Jurnal Agrosains dan Teknologi 1(2): 48-63.

Herista M I. 2015. Sikap dan preferensi konsumen buah jeruk lokal dan buah jeruk impor (kasus kota Bandar Lampung provinsi Lampung) [tesis]. Bogor: Institut Pertanian Bogor.

Hubeis M, Widyastuti H, Wijaya N H. 2014. Prospek cerah produksi sayuran organik bernilai tambah tinggi berbasis petani. Jurnal Risalah Kebijakan Pertanian dan Lingkunga 1(2):110-115.

Kotler P. 2011. Manajemen Pemasaran di Indonesia: Analisis, Perencanaan, Implementasi dan Pengendalian. Jakarta: Penerbit Salemba Empat.

Lubis A S, Andayani N R. 2017. Pengaruh kualias pelayanan (service quality) terhadap kepuasan pelanggan PT. Sucofindo Batam. Journal of Business Administration 1(2):232-243.

Nandan N, Gami A. 2015. Organic farming: A new revolution in agriculture. Journal of Agroecology and Natural Resource Management 2(1): 12-13.

Organic Institute, Yayasan Alifa, Kombas.id. 2019. Statistik Pertanian Organik Indonesia. Bogor: Aliansi Organis Indonesia.

Puspasari E D, Sarma M, Najib M. 2017. Preferensi konsumen dan strategi pemasaran produk puree bayam organik (studi kasus: CV Addin Abadi Bogor). Jurnal Teknologi Industri Pertanian 27(2): 209-216. 
Rachmadita R N, Arninputranto W. 2018. Analisis kepuasan pemustaka terhadap kualitas layanan perpustakaan di perguruan tinggi vokasi dengan metode Servqual dan Importance Performance Analysis. Jurnal Berkala Ilmu Perpustakaan dan Informasi 14(2): 214-225.

Ratnawati E, Rahayu E S, Irianto H. 2017. Analisis faktor-faktor yang dipertimbangkan konsumen dalam pembelian sayuran orrganik di kota Surakarta. Jurnal Agrista 5(1):25-35.

Rusyadi Y. 2014. Analisis sikap dan kepuasan petani terhadap atribut benih padi hibrida maro di kabupaten subang [tesis]. Bogor: Institut Pertanian Bogor.

Sangadji EM, Sopiah. 2013. Perilaku Konsumen Pendekatan Praktis Disertai Himpunan Jurnal Penelitian. Yogyakarta: Andi Offset.

Sari H, Setiaboedhi A P. 2017. Faktor-faktor yang memengaruhi minat beli pangan organik melalui situs online. Jurnal Manajemen \& Agribisnis 14(1).

Sarma M, Nanere M, Trebilcock P. 2020. Pricing strategies for organic vegetables based on Indonesia consumer willingness to pay. Journal Management Science Letters p 3253-3264. doi: 10.5267/j.msl.2020.6.013.

Sugiyono. 2016. Metode Penelitian Kombinasi. Bandung: Alfabeta.

Supranto MA. 2011. Pengukuran Tingkat Kepuasan Pelanggan Untuk Menaikkan Pangsa Pasar. Jakarta: Rineka Cipta.

Suroto, Nindiani A, Purba H H. 2017. Students' satisfaction on academic services in higher education using importance performance analysis. Jurnal ComTech 8(1):37-43.

Sutarni, Trisnanto T B, Unteawati. 2017. Preferensi terhadap atribut produk sayuran organik di Kota Bandar Lampung. Jurnal Penelitian Pertanian Terapan 17(3): 203-211.

Yasmin T R, Prastiwi W D, Handayani M, 2017. Analisis konjoin preferensi konsumen sayuran hidroponik agrofarm bandungan Kabupaten Semarang. Jurnal Sosial Ekonomi Pertanian 1(1): 85-93.

Yadaf S K, Babu S, Yadaf M K, Singh K, Yadaf G S, Pal S. 2013. A review of organic farming for sustainable agriculture in Northern India. International Journal of Agronomy, Article ID 718145,8 page. 